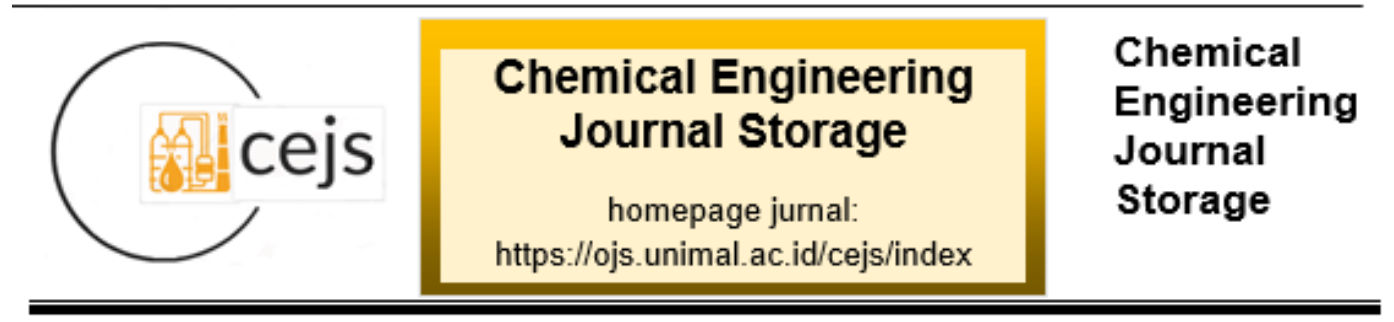

\title{
PRODUKSI GAS HIDROGEN DARI AIR LAUT DENGAN PROSES ELEKTROLISIS MENGGUNAKAN ELEKTRODA LOGAM (TITANIUM) DAN NON LOGAM (KARBON)
}

\author{
Muhammad Abrar, Lukman Hakim*, Suryati \\ Jurusan Teknik Kimia, Fakultas Teknik, Universitas Malikussaleh \\ Kampus Utama Cot Teungku Nie Reuleut, Muara Batu, Aceh Utara - 24355 \\ Korespondensi: HP: 0852-9614-8295, Email: lukman_hakim@unimal.ac.id
}

\begin{abstract}
Abstrak
Dalam memenuhi kebutuhan pasokan energi dalam negeri, salah satu penelitian mengenai energi terbarukan yang pada saat ini dikembangkan adalah pemanfaatan bahan bakar hidrogen yang digunakan dalam Fuel Cell System. Penelitian ini bertujuan untuk meningkatkan produksi gas hidrogen yang sebelumnya hanya mengandalkan gas alam, pembuatan gas hidrogen sebagai energi terbarukan diharapkan menjadi terobosan baru dalam mendukung energi yang ramah lingkungan. Pada penelitian ini melakukan metode elektrolisis menggunakan arus listrik searah atau DC (Power Supply) dan air laut dengan volume elektrolit $1000 \mathrm{ml}$, waktu elektrolisis 2, 4, 6, 8, dan 10 menit dengan menggunakan elektroda Titanium dan Karbon dan memvariasikan tegangan 5, 10, 15, 20 dan 25 volt. Pemilihan jenis reaktor berbentuk silinder berkapasitas $1500 \mathrm{ml}$, kondisi operasi $30^{\circ} \mathrm{C}$ dan 1 atm. Hasil kajian menunjukkan bahwa tegangan sangat berpengaruh terhadap penguraian air laut menjadi gas hidrogen. Dengan menggunakan elektroda titanium didapat hasil flow rate gas hidrogen yang paling tinggi di dapat pada tegangan 25 volt dengan waktu 8 menit sebesar $247 \mathrm{cc} / \mathrm{min}$ dengan elektroda Titanium yang tidak terdegradasi sedangkan dengan elektroda Karbon didapat $318 \mathrm{cc} / \mathrm{min}$ pada 25 volt dengan waktu 10 menit namun elektroda karbon lebih cepat terdegradasi. Sedangkan jumlah volume Sodium Hipoklorit yang terbentuk sangat dipengaruhi oleh tegangan dan waktu elektrolisis.
\end{abstract}

Kata kunci : elektroda, energi, Hidrogen, Karbon, Sodium Hipoklorit, Titanium

\section{Pendahuluan}

Kelangkaan gas bumi yang sedang berlangsung saat ini menyebabkan kita perlu memiliki alternatif lain dalam menghasilkan gas $\mathrm{H}_{2}$ sehingga produksi dapat terus berjalan meskipun dalam kondisi yang sedang tidak memungkinkan. Hal inilah yang mendorong berbagai pakar energi untuk mengembangkan teknologi sehingga dapat memperoleh energi yang lebih ramah lingkungan dan terjamin 
jumlah dan ketersediannya dalam jangka waktu yang Panjang (Tumimomor et al., 2012).

Krisis energi gas di Indonesia telah dimulai awal tahun 2010 ini karena pasokan gas tidak seperti yang direncanakan oleh pemerintah. Sementara itu dengan membaiknya perekonomian global, permintaan atau kebutuhan gas di sektor industri dan ketenagalistrikan juga meningkat. Selain itu, patut diduga kelangkaan gas saat ini terjadi karena BP Migas sebagai regulator dan Kementerian Energi dan Sumber Daya Mineral (ESDM) tidak mampu menangani sektor Migas dengan baik (Sutoto, 2009) .

Indonesia memiki cadangan gas alam yang besar. Saat ini, negara ini memiliki cadangan gas terbesar ketiga di wilayah Asia Pasifik (setelah Australia dan Republik Rakyat Tiongkok), berkontribusi untuk 1,5\% dari total cadangan gas dunia. Kebanyakan pusat-pusat produksi gas Indonesia berlokasi di lepas pantai. Yang paling besar di antaranya adalah: Arun, Aceh (Sumatra), Bontang (Kalimantan Timur), Tangguh (Papua), dan Pulau Natuna (Ginting, 2010).

Sampai saat ini lebih dari $85 \%$ kebutuhan hidrogen dunia diproduksi dengan proses steam reforming gas alam, yang beroperasi pada temperatur tinggi $\left(800^{\circ}\right.$ $1000^{\circ} \mathrm{C}$ ) dengan sumber energi panas pembakaran bahan bakar fosil. Pembakaran bahan bakar fosil sebagai sumber energi panas, berakibat pada tingkat pemborosan cadangan bahan bakar fosil serta peningkatan emisi $\mathrm{CO}_{2}$ yang cukup besar. Substitusi sumber energi panas dengan reaktor nuklir dapat mengurangi laju pengurasan cadangan bahan bakar fosil, sekaligus menurunkan laju emisi $\mathrm{CO}_{2}$ (Taspika, 2015).

\section{Bahan dan Metode}

Air laut sebanyak $1000 \mathrm{ml}$ dimasukkan kedalam reaktor elektrolisis yang telah dipasang elektroda berukuran $20 \mathrm{~cm}$ x $1,5 \mathrm{~cm}$ yang terhubung dengan power supply dengan tegangan 5, 10, 15, 20, dan 25 volt. Reaktor dipasang dan ditutup dengan selotip pada bagian atasnya dan ditambahkan lem kaca pada celah reaktor agar gas hydrogen yang terbentuk seluruhnya tersalurkan ke selang yang menghubungkan ke bubble flow meter. Proses ini divariasikan selama 2,4,6,8, dan 
10 menit untuk mendapatkan gas hidrogen yang terbentuk dari perpindahan elektron yang terjadi. Gas yang terbentuk akan disalurkan melalui selang menuju bubble flow meter untuk dilihat jumlah gas hidrogen yang terbentuk. reaktor juga dilengkapi dengan thermometer untuk mengetahui seberapa banyak kalor yang diterima oleh larutan elektrolit. Selanjutnya Sodium Hipoklorit yang terbentuk dimasukkan kedalam beaker gelas untuk diukur volumenya dan dicatat dan akan dihitung kadar chlorine didalamnya. Gas hidrogen yang sudah terbentuk kemudian diuji kemampuan daya bakarnya dengan mengubah tujuan selang reaktor dari bubble flow meter ke lilin yang menyala dan dilihat apakah terjadi letupan pada ujung lidah api atau tidak.

Untuk mendapatkan jumlah flow gas hidrogen perlu dilakukan analisa flow rate dengan bubble flow meter, sedangkan untuk mengetahui kadar chlorine dalam Sodium hipoklorit diperlukan pengujian menggunakan spectrometer UVVIS 1900 (Nielsen, 2006).

\subsection{Menghitung Flow Rate Gas Hidrogen}

Adapun tahapan menghitung flow rate gas hidrogen pada penelitian ini, yaitu:

1. Keluaran dari reaktor dihubungkan dengan Bubble flow meter.

2. Cairan dalam Bubble flow meter akan menghasilkan gelembung

3. Gelembung akan di dorong oleh gas hidrogen yang masuk

4. Nyalakan Stopwatch pada saat gelembung berada pada garis batas $0 \mathrm{cc}$

5. Hentikan Stopwatch pada saat gelembung berada pada salah satu garis batas yang di pilih.

\subsection{Analisa Kualitas Daya Bakar Gas Hidrogen}

Adapun tahapan analisa kualitas daya bakar gas hidrogen pada penelitian ini, yaitu:

1. Gas hidrogen dari reaktor dilepaskan dari bubble flow meter,

2. Dibiarkan proses elektrolisis terus berjalan,

3. Dinyalakan api dan didekatkan pada selang produk hidrogen, 
4. Diharuskan berhati-hati dalam melakukannya dikarenakan sifat dari pada gas hidrogen yang mudah terbakar akan menghasilkan letupan.

\subsection{Analisa Jumlah Volume Natrium Hipoklorit}

Adapun tahapan analisa jumlah volume Natrium Hipoklorit pada penelitian ini, yaitu:

1. Natrium Hipoklorit yang terbentuk dimasukkan kedalam beaker glass,

2. Dicatat hasil yang didapat terhadap masing-masing run.

\subsection{Analisa Kandungan Chlorine dalam Natrium Hipoklorit}

Adapun tahapan analisa kandungan Chlorine dalam Natrium Hipoklorit pada penelitian ini, yaitu (Tumimomor et al., 2012):

1. Larutan elektrolit di saring dengan menggunakan kertas saring,

2. Kemudian dimasukkan ke dalam labu ukur sebanyak $25 \mathrm{ml}$,

3. Ditambahkan aquades sebanyak $25 \mathrm{ml}$,

4. Diteteskan Reagent A (Ferrous Amm. Sulfate $5 \%$ ) sebanyak $5 \mathrm{ml}$ dan Reagent B (Mercury Thiocynate 0,3\%) sebanyak 2,5 ml,

5. Larutan dihomogenkan,

6. Larutan blanko dimasukkan ke dalam 2 kuvet dan diletakkan sejajar dalam alat spektrofotometri UV-VIS,

7. Ditekan tombol start, dan pastikan nilai absorb adalah 0 ,

8. Diganti salah satu kuvet dengan larutan Sodium Hipoklorit yanag ingin dianalisa, dan

9. Dicatat nilai absorb yang diperoleh dan didapat jumlah kandungan chlorine dalam larutan sampel.

\section{Hasil dan Pembahasan}

Pada penelitian produksi gas hidrogen dari air laut dengan metode elektrolisis hasil yang didapat pada penelitian dapat dilihat pada tabel 3.1

Tabel 3.1 Hasil Penelitian dengan Elektroda Titanium. 


\begin{tabular}{|c|c|c|c|c|c|c|c|}
\hline \multirow[b]{2}{*}{ Run } & \multirow[b]{2}{*}{$\begin{array}{c}\text { Tegangan } \\
\text { (Volt) }\end{array}$} & \multirow[b]{2}{*}{$\begin{array}{l}\text { Waktu } \\
\text { (menit) }\end{array}$} & \multicolumn{3}{|c|}{ Elektroda Titanium } & \multicolumn{2}{|c|}{ Elektroda Karbon } \\
\hline & & & $\begin{array}{c}\text { Temp. } \\
\text { (C) }\end{array}$ & $\begin{array}{c}\text { Flow Rate } \\
\text { (cc/min) }\end{array}$ & $\begin{array}{c}\text { Volume } \\
\text { HClO } \\
(\mathrm{ml})\end{array}$ & $\begin{array}{c}\text { Temp. } \\
\text { (C) }\end{array}$ & $\begin{array}{c}\text { Flow Rate } \\
\text { (cc/min) }\end{array}$ \\
\hline \multirow{5}{*}{ I } & \multirow{5}{*}{5} & 2 & 31 & 0 & 0 & 31 & 8 \\
\hline & & 4 & 31 & 0 & 0 & 31 & 7 \\
\hline & & 6 & 31 & 0 & 0 & 31 & 8 \\
\hline & & 8 & 31 & 0 & 0 & 31 & 9 \\
\hline & & 10 & 31 & 0 & 0 & 32 & 9 \\
\hline \multicolumn{3}{|c|}{ Rata-rata } & 31 & $\mathbf{0}$ & $\mathbf{0}$ & 31,2 & 8,2 \\
\hline \multirow{5}{*}{ II } & \multirow{5}{*}{10} & 2 & 31 & 2 & 0 & 32 & 15 \\
\hline & & 4 & 31 & 2 & 0 & 32 & 18 \\
\hline & & 6 & 32 & 2 & 1 & 32 & 17 \\
\hline & & 8 & 33 & 2 & 1 & 32 & 20 \\
\hline & & 10 & 33 & 3 & 1 & 32 & 18 \\
\hline \multicolumn{3}{|c|}{ Rata-rata } & 32 & 2,2 & 0,6 & 32 & 17,6 \\
\hline \multirow{5}{*}{ III } & \multirow{5}{*}{15} & 2 & 32 & 8 & 3 & 32 & 66 \\
\hline & & 4 & 32 & 20 & 5 & 32 & 70 \\
\hline & & 6 & 33 & 66 & 7 & 32 & 84 \\
\hline & & 8 & 35 & 75 & 8 & 33 & 69 \\
\hline & & 10 & 39 & 87 & 11 & 34 & 75 \\
\hline \multicolumn{3}{|c|}{ Rata-rata } & 34,2 & 51,2 & 6,8 & 32,6 & 72,8 \\
\hline \multirow{5}{*}{ IV } & \multirow{5}{*}{20} & 2 & 33 & 82 & 18 & 32 & 127 \\
\hline & & 4 & 35 & 114 & 37 & 32 & 138 \\
\hline & & 6 & 42 & 130 & 50 & 33 & 135 \\
\hline & & 8 & 45 & 122 & 88 & 33 & 168 \\
\hline & & 10 & 48 & 128 & 98 & 34 & 174 \\
\hline \multicolumn{3}{|c|}{ Rata-rata } & 40,6 & 115,2 & 58,2 & 32,8 & 148,4 \\
\hline \multirow{5}{*}{ V } & \multirow{5}{*}{25} & 2 & 34 & 165 & 73 & 34 & 210 \\
\hline & & 4 & 38 & 210 & 86 & 35 & 256 \\
\hline & & 6 & 46 & 240 & 102 & 36 & 285 \\
\hline & & 8 & 54 & 247 & 115 & 40 & 306 \\
\hline & & 10 & 58 & 238 & 138 & 42 & 318 \\
\hline \multicolumn{3}{|c|}{ Rata-rata } & 46 & 220 & 102,8 & 37,4 & 275 \\
\hline
\end{tabular}

Sumber: Hasil penelitian 2021

\subsection{Pengaruh Waktu Elektrolisis \& Tegangan Terhadap Flow Rate Gas Hidrogen}

Dalam penelitian elektrolisis ini pengaruh waktu dan tegangan terhadap flow rate gas hidrogen dengan menggunakan elektroda titanium dan karbon dapat dilihat pada gambar 3.1 


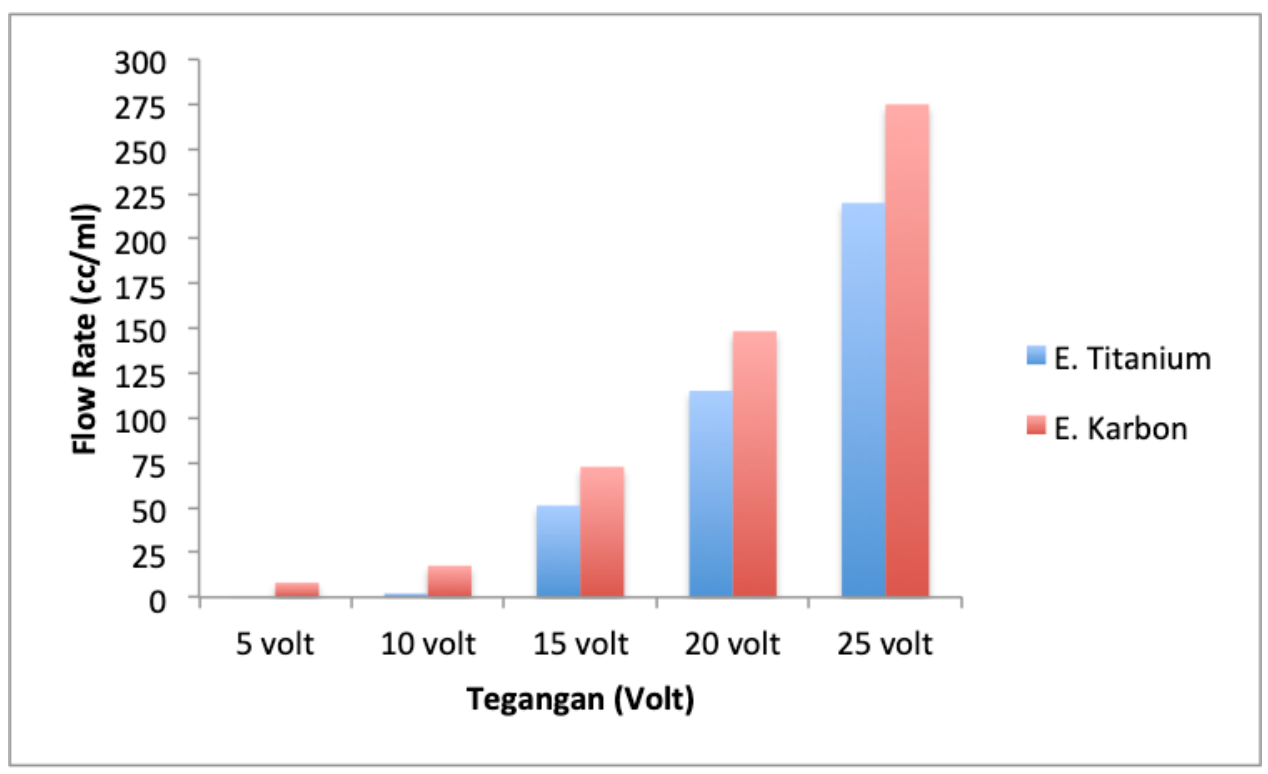

Gambar 3.1 Hubungan Waktu dan Tegangan Terhadap Flow Rate Gas Hidrogen

Dari grafik diatas dapat dilihat bahwa waktu elektrolisis kurang berpengaruh dalam menghasilkan flow rate gas hidrogen. Sehingga dapat kita ketahui bahwa penguraian air laut menjadi gas hidrogen sedikit dipengaruhi oleh lamanya waktu elektrolisis. Berdasarkan pengamatan di atas pada besaran tegangan yang diberikan, menghasilkan flow rate gas hidrogen yang berbeda-beda. Dari grafik diatas dapat kita lihat semakin besar tegangan yang diberikan maka flow rate gas hidrogen dan warna larutan menjadi semakin kecoklatan.

\subsection{Pengaruh Waktu Elektrolisis dan Tegangan Terhadap Temperatur}

Pengaruh waktu dan tegangan terhadap temperatur yang di hasilkan pada penelitian elektrolisis dengan elektroda titanium dapat dilihat pada gambar 3.2 


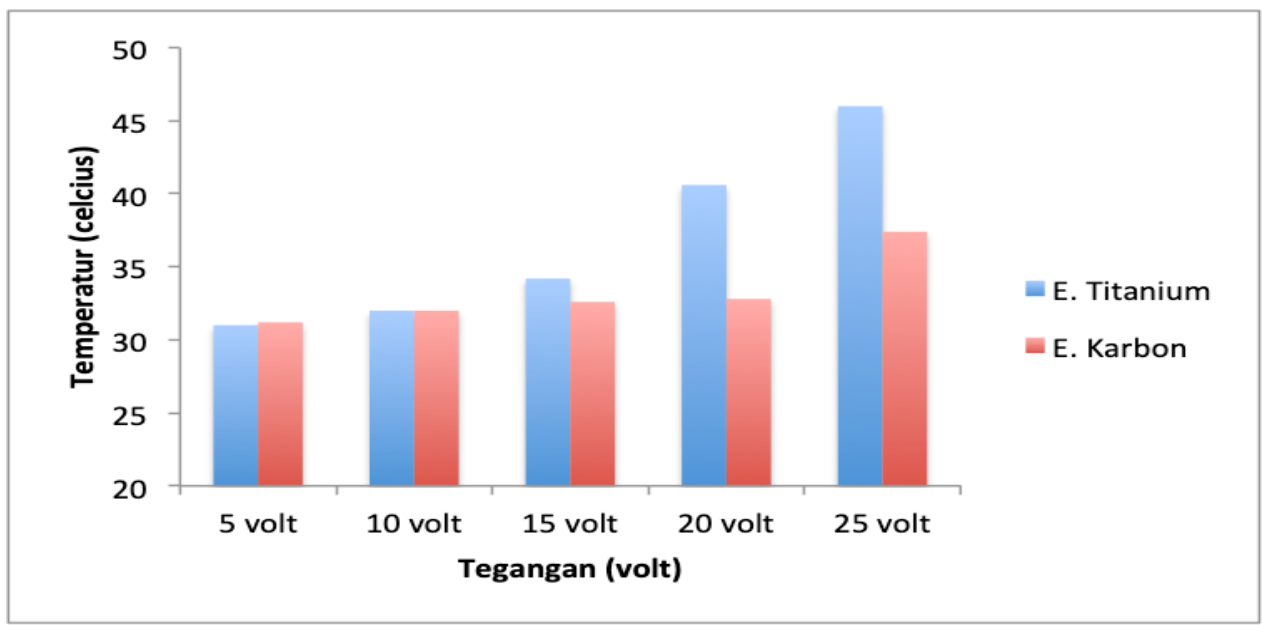

Gambar 3. Hubungan Waktu dan Tegangan Terhadap Temperatur

Perubahan suhu reaksi berbanding lurus dengan lamanya waktu elektrolisis dan besarnya tegangan yang diberikan pada elektroda. Hal ini disebabkan oleh semakin lama energi listrik yang diberikan maka semakin besar energi listrik yang berubah menjadi energi panas yang selanjutnya akan diserap oleh larutan elektrolit. Semakin lama energi listrik yang diberikan maka semakin besar energi listrik yang berubah menjadi energi panas yang selanjutnya akan diserap oleh larutan elektrolit.

\subsection{Pengaruh Tegangan dan Waktu Terhadap Jumlah Volume Sodium Hipoklorit}

Pengaruh Tegangan dan waktu terhadap jumlah volume Sodium Hipoklorit yang di hasilkan pada penelitian elektrolisis ini dapat dilihat pada gambar 3.3 dibawah ini.

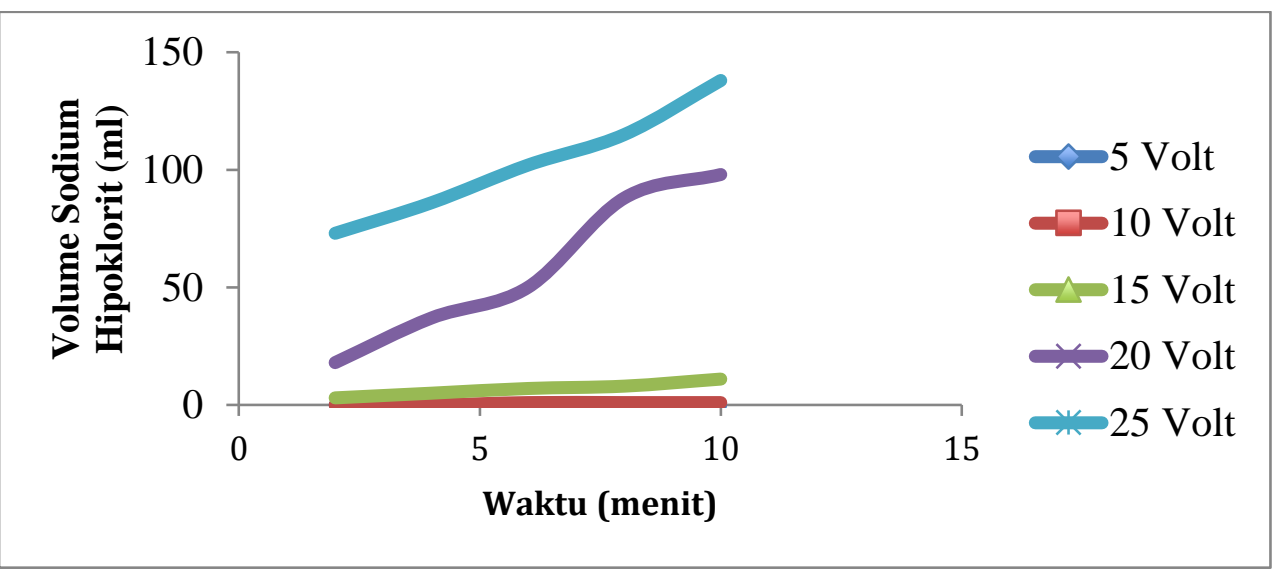


Gambar 3.7 Hubungan Tegangan dan Waktu Terhadap Jumlah Volume Sodium Hipoklorit

Dari reaksi elektrolisis yang dilakukan dengan elektroda didapat jumlah hipoklorit yang sangat bervariasi. Jumlah yang dihasilkan sangat bergantung pada besarnya tegangan yang diberikan dan durasi waktu dilakukannya elektrolisis.

\subsection{Pengujian Kadar Chlorine Dalam Sodium Hipoklorit}

Dari hasil sampel larutan elektrolit 15 volt yang diuji diperoleh nilai kadar chlorine dalam Sodium Hipoklorit memakai elektroda Titanium sebesar 57 ppm, sedangkan dengan menggunakan elektroda karbon didapat 54 ppm.

\section{Kesimpulan}

Berdasarkan hasil penelitian Produksi hidrogen dari air laut dengan proses elektrolisis menggunakan elektroda Titanium dan Karbon dapat diambil kesimpulan:

1. Tegangan (volt) sangat berpengaruh terhadap flow rate gas hidrogen yang terbentuk dalam proses hidrolisis,

2. Elektroda Titanium tidak mudah mengalami degradasi (meskipun ada sedikit), sedangkan elektroda Karbon mudah untuk terjadi degradasi dan membuat larutan berwarna coklat akibat dari berpindahnya atom-atom karbon ke larutan elektrolit,

3. Pada tegangan 5 dan 10 Volt tidak terjadi pertukaran ion sehingga baik gas Hidrogen maupun Sodium Hipoklorit tidak terbentuk akibat energi yang diterima tidak mampu mengalirkan elektron,

4. Endapan Sodium Hipoklorit terbanyak dihasilkan pada tegangan 25 volt dengan waktu 10 menit yaitu sebesar $138 \mathrm{ml}$, dan

5. Flow rate gas hidrogen tertinggi terdapat pada tegangan 25 volt dengan waktu 10 menit yaitu sebesar $247 \mathrm{cc} / \mathrm{min}$ dengan memakai elektroda titanium dan $318 \mathrm{cc} / \mathrm{min}$ dengan elektroda karbon.

\section{Daftar Pustaka}

Ginting, A. H. (2010). Simulasi Sistem Kontrol Klorinasi Pada Pembangkit 
Listrik Tenaga Uap Sebalang Unit 5 \& 6 Lampung Selatan. Journal of Chemical Engineering, 2(3), 6.

Nielsen, B. C. (2006). Control of Ballast Water Organisms with a Seawater Electrochlorination and Filtration System. Journal of Chemical Engineering, 10(4), 18.

Sutoto. (2009). Karakterisasi Elektroda Titanium Untuk Regenerasi Elektrolit Dekontaminasi Secara Elektrodeposing. Journal of Chemical Engineering, 14(2), 12.

Taspika, A. M. (2015). Pembuatan Elektroda Kapasitor Karbon Berpori Dari Tempurung Kemiri (Aleurites Moluccana) Sebagai Sistem Capacitive Deionization. Journal of Chemical Engineering, 13(1), 8.

Tumimomor, F., Maddu, A., \& Pari, G. (2012). Pemanfaatan Karbon Aktif Dari Bambu Sebagai Elektroda Superkapasitor. Journal of Chemical Engineering, 23(3), 10. 